United States

Department of

Agriculture

Forest Service

U:S

Southeastern Forest

Experiment Station

Research Paper

SE-260
Recent Area Changes

in Southern Forest

Ownerships and Cover Types

Ralph J. Alig

Herbert A. Knight

Richard A. Birdsey 


\title{
Recent Area Changes in Southern Forest Ownerships and Cover Types
}

\author{
Ralph J. Alig, Project Leader \\ Southeastern Forest Experiment Station \\ Research Triangle Park, North Carolina \\ Herbert A. Knight, Resource Analyst \\ Southeastern Forest Experiment Station \\ Asheville, North Carolina
Richard A. Birdsey, Research Forester
Southern Forest Experiment Station
New Orleans, Louisiana

\begin{abstract}
Forest area data were examined from the most recent surveys of the 12 southern states by the Forest Inventory and Analysis units of the USDA Forest Service. From 1977 to 1985, forest industry acreage in the South has continued to increase, miscellaneous private acreage has increased at a slower rate, and farm forest acreage has continued to drop sharply. During the same period, the largest area changes among cover types have occurred in pine types. Area in natural pine has decreased 18 percent, and planted pine area has increased by 41 percent.

Keywords: Forest area, timber supply, forest ownership.
\end{abstract}

The South is an increasingly important source of timber. Currently, southern timberland provides two-thirds of the domestic roundwood used in the pulp industry, one-third of the timber used in the lumber industry, about twofifths of the timber used in the veneer and plywood industry, and a large portion of that used in producing other miscellaneous timber products in the United States. Further, most of the expansion in the timber products industry in the United States over the next few decades is likely to be based on southern timber resources (USDA Forest Service 1982).
This Paper describes recent changes in the area of southern timberland, including changes by ownership and cover type. The discussion also highlights other significant regional changes, such as timberland leasing and land acquisition by miscellaneous private corporate owners. Historical changes in the area of southern timberland are discussed elsewhere (e.g., USDA Forest Service 1982). The focus here is on recent changes.

\section{Land Use Changes}

Land use competition among several sectors of the economy is expected to be particularly intense over the next decade or so in the South. Key economic sectors that are dependent on land include crop agriculture, livestock agriculture (grazing), and forestry. Timberland currently occupies about three-fifths of the land in the South, but this proportion could rise or fall in the years ahead. A USDA study (1983) estimated that some 17 million acres now in cropland and pasture in nine Southern States could yield higher average annual net returns per acre in pine plantations. An earlier study of potential cropland, however, estimated that approximately 20 million acres of timberland in 12 Southern States had medium or high potential as cropland (Dideriksen and others 1977). 
High interest rates and declining export markets have created uncertainty about the financial position of many farmers. Unattractive returns from farming ventures could cause an increased rate of reversion of marginal cropland to forest. Overall, the potential for shifts in land use is large, and the net effect on forest acreage is hard to predict.

A key aspect of timber availability in the South is the large proportion of forest acreage that is controlled by nonindustrial private forest (NIPF) owners. Forest industry owns or leases about 23 percent of the timberland in the South, and various levels of government control another 10 percent. NIPF owners of various sorts control the remainder. Thus, decisions about management of the majority of the southern forests are made neither by government officials nor by corporate officials. They are made by hundreds of thousands of individuals pursuing their own interests, guided by market and nonmarket objectives. Changes are tracked after the fact by analyzing the results of forest surveys, as we do in this Paper.

\section{Recent Forest Acreage Changes}

Forest acreages of individual States are estimated periodically in Forest Inventory and Analysis (FIA) surveys by the USDA Forest Service (e.g., Knight 1973). The entire South is resurveyed in approximately 10-year cycles. The area is divided between two subregions: the Southeast, including Florida, Georgia, North Carolina, South Carolina, and Virginia; and the Midsouth, including Alabama, Arkansas, Louisiana, Mississippi, east Oklahoma, Tennessee, and east Texas.

For an ongoing Forest Service study of the southern timber resource, the State FIA surveys were updated to 1985 by FIA experts. The previous update for the southern FIA surveys was for the year 1977 (USDA Forest Service 1982).

\section{Land Base}

Recent FIA surveys indicate that timberland's share of the land base has been decreasing for a decade or more in all the Southern States except Alabama and Tennessee, where timberland's share has increased slightly. Regionwide, forest area has dropped by 4.5 million acres since 1977 .

Net changes in forest area for the Southern States result in part from shifts among cropland, pasture, and forest. Periodic surveys by the Census of Agriculture suggest that some of the diverted forest land was planted to crops. Between 1974 and 1982, the area of cropland (harvested, crop failure, and cultivated summer fallow) in the South increased by approximately 7 million acres. During the same period, pasture and rangeland decreased by about 2 million acres in the two forest survey regions (which exclude large parts of Texas and Oklahoma). These shifts reflect trends in relative income obtainable from the alternative uses. Generally, real crop incomes per acre have risen since the $1960^{\prime} \mathrm{s}$, whereas real livestock income indices have declined (Alig 1984). Comparable standardized indices for income from forest land are not available.

Forest area has also been reduced by continued clearing for urban and related developed uses. Urban expansion has been driven in part by a population increase of more than 40 percent in the South from 1960 to 1980 . Over that same time period, per-capita real personal income in the South has approximately doubled, creating additional pressure to develop land (Alig 1985).

Conversions to built-up uses represent very long-term removals from the forest land base. Shifts of forest land to urban and other built-up uses also differ from shifts to agricultural uses in that urbanization often restricts cultural operations on nearby or adjoining rural land. 
The extent to which land that is urbanized comes out of forest rather than agricultural uses cannot be suitably answered with current data. Analysis of one data set by Healy (1984) indicated that high-quality rather than low-quality forest land was converted (to both urban and agricultural uses), while analysis of another data set indicated just the opposite. Other studies indicate that urban and built-up uses occur disproportionately on prime agricultural land (Cousins and Dillman 1982; Ramsey and Corty 1982). Overall, these studies suggest that land in the South is not converted to urban uses in a given locality in proportion to the relative acreage in each rural use, which is about 60 percent for forest land.

\section{Land Productivity}

Statistical analysis of FIA data first assembled around the mid-1960's indicates no significant changes at the regional level in the distribution of timberland by site for owner classes. The last two forest surveys in the Southeast indicate relatively minor shifts toward the higher site classes (table 1).
Net changes in the distribution of site classes by forest type have also been relatively small, except for the lowland hardwood class. Data for the Southeast indicate a large drop in the lowland hardwood area in the upper site class. A major cause is conversion of high-quality timberland to agriculture, including soybean production.

\section{Forest Ownership}

Since 1977, the largest area changes for forest ownerships in the South have occurred on forest industry and NIPF land (fig. 1). Forest industry acquired more than a million acres of southern timberland. The expansion was about equally divided between the two subregions .

Over an extended period, many forest products manufacturing companies have found it advantageous to own large amounts of forest land. Perceived advantages include an assured wood supply for mills that represent very large investments, augmented surplies of low-cost timber, an inflationary hedge, and certain tax advantages (Clephane 1978; Clephane 1980; O'Laughlin and Ellefson 1982). While the specific

Table 1.--Changes in the percentage distribution of southeastern timberland, by site class in each ownership category, between last two surveys

\begin{tabular}{|c|c|c|c|c|c|c|}
\hline \multirow[b]{2}{*}{$\begin{array}{c}\text { Ownership } \\
\text { class }\end{array}$} & \multirow{2}{*}{$\begin{array}{l}\text { High site } \\
\text { Previous } \\
\text { survey }\end{array}$} & \multirow{2}{*}{$\begin{array}{l}\text { class } \\
\text { Latest } \\
\text { survey }\end{array}$} & \multicolumn{2}{|c|}{ Medium site class } & \multicolumn{2}{|c|}{ Low site class } \\
\hline & & & $\begin{array}{c}\text { Previous } \\
\text { survey }\end{array}$ & $\begin{array}{l}\text { Latest } \\
\text { survey }\end{array}$ & $\begin{array}{c}\text { Previous } \\
\text { survey }\end{array}$ & $\begin{array}{l}\text { Latest } \\
\text { survey }\end{array}$ \\
\hline National Forest & 17 & 18 & 54 & 50 & 29 & 32 \\
\hline Other public & 16 & 21 & 54 & 50 & 30 & 29 \\
\hline Forest industry & 23 & 22 & 63 & 64 & 14 & 14 \\
\hline $\begin{array}{l}\text { Nonindustrial } \\
\text { private }\end{array}$ & 22 & 22 & 58 & 61 & 20 & 17 \\
\hline All owners & 21 & 22 & 59 & 61 & 20 & 17 \\
\hline
\end{tabular}





Pigure 1.- Timberland area by ownership in 1977 and 1985.

gains may be difficult to identify in individual cases, advantages must exist, because the top 20 forest products manufacturing companies in the United States all own significant amounts of timberland (0'Laughlin and Ellefson 1982).
The latest survey data do not indicate that purchase of timberland by forest industry in the South has slackened, but future surveys might. Today, such ownership is under attack in many companies that are experiencing cash-flow problems. Investments other than land could, in some instances, provide more attractive returns. As a result, large amounts of forest industry land have been reported for sale, although few transactions appear to have actually occurred. In addition, forest industry in some cases is substituting intensive forestry practices for increased land acquisition.

Two attractive substitutes for direct ownership of forest land for forest products manufacturers are long-term land leases and long-term cutting rights. According to FIA statistics, long-term leasing (one timber rotation or longer) of NIPF land by forest industry (excluding land under cutting contracts) increased by approximately one-half million acres over the last FIA remeasurement cycle. About 4 million acres are under lease to forest industry; this area represents more than 10 percent of industry's fee simple ownership. Forest industry manages about one-third of the southern pine acreage in the region either through outright ownership or long-term lease. Two-thirds of the land under long-term lease to forest industry is occupied by pine. According to surveys by Siegel (1973) and Meyer and Klemperer (1984), nonindustrial private acreage under long-term (10 years or more) land lease and cutting contracts by forest industry decreased by approximately 2 million acres between 1970 and 1983, and forest industry is favoring landowner assistance programs over long-term contracts.

The increase in forest industry acreage has been largely at the expense of NIPF land. We have divided the NIPF land into three categories: (1) farm, (2) other individual, and (3) other corporate (corporations other than forest industry). The acreage of NIPF land has decreased by 5 percent since 1977 because of changes in land ownership and use. 
The acreage of farm woodland in the South has decreased by 18 percent since 1977. At the same time, the forest area controlled by corporations that do not manufacture forest products has increased by 20 percent, or 3 million acres. The additional acres acquired by corporations since 1977 are spread across all of the major forest types: planted southern pine, 32 percent; natural southern pine, 7 percent; oak-pine, 16 percent; upland hardwoods, 34 percent; and lowland hardwoods, 16 percent.

Clephane and Carroll (1981) gave two major reasons why timberland ownership has appealed to corporate and individual investors in recent years: (1) increasing value of timber assets and (2) the U.S. low-cost position in world markets. To what degree such owners will invest in intensified management or how much land they will sell after harvest are open questions. For these owners, timberland investments compete with other, more diverse investment opportunities than they do for traditional wood-based companies (0'Laughlin and Ellefson 1982).

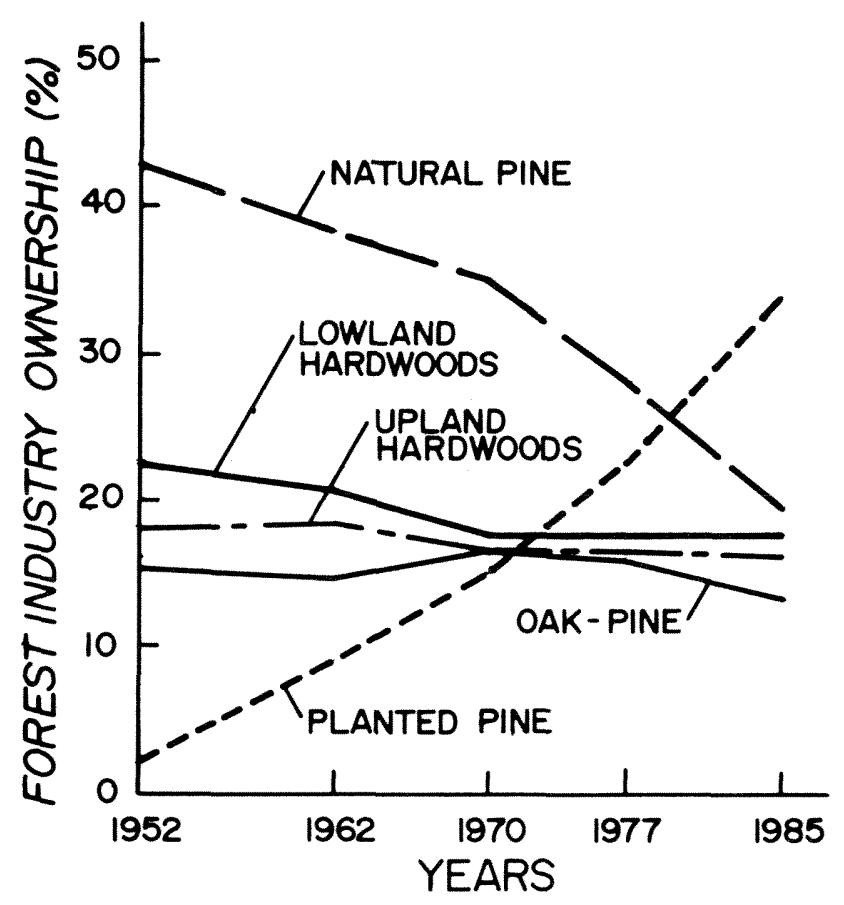

Figure 2.--Distribution of forest types on forest industry land in the south from 1952 to 1985 .
Area of public timberland in the South has changed little since 1977, and still accounts for about 10 percent of southern timberland. Additions to public timberland have been spread across all cover types except natural pine. About three-fifths of public timberland is National Forest.

\section{Forest Cover Types}

The regional distribution of cover types on southern timberland has been relatively stable except for substitution of planted pine for natural pine and an increase in NIPF upland hardwood acreage (figs. 2, 3). The area in pine plantations has increased at an annual rate of approximately 0.9 million acres since 1977. An annual reduction of 1.2 million acres in the natural pine area, however, has resulted in an overall net loss of more than 2 million acres since 1977 .

About three-fourths of the increase in area of planted pine since 1977 has occurred on forest industry land. The annual rate of area increase for industry plantations has risen from 0.2

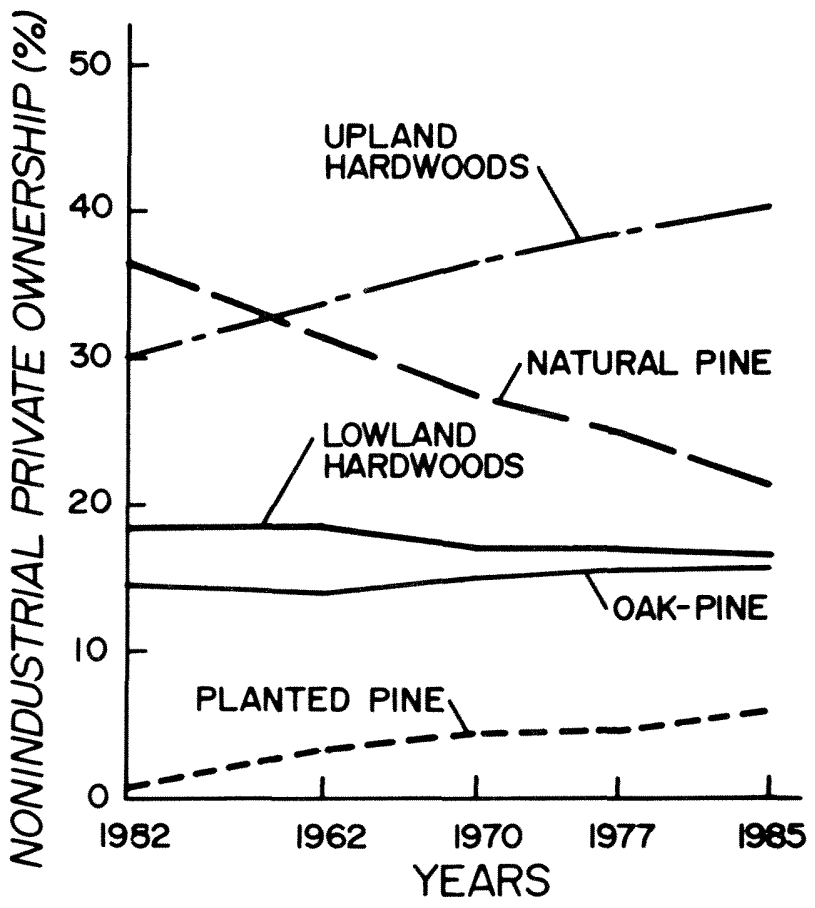

Figure 3.--Distribution of forest types on nonindustrial private forest land in the South from 1952 to 1985. 
million acres in the $1950^{\prime} \mathrm{s}$ to 0.7 million acres in the late 1970's and early 1980's. A large proportion of the area from which natural pine stands were removed has been planted to pine.

Total acreage of upland hardwoods in the South has slowly expanded. This trend is the reverse of that for lowland hardwoods. Clearing of bottom-land hardwood forest has continued, but at a declining rate. In contrast, the increase in upland hardwood acreage, particularly on NIPF land, is principally the result of successional forces. The oak-pine type has slowly declined since a peak in 1970 .

Changes in the distribution of forest types reflect the combined influences of vegetation dynamics and shifts in land use. The interaction of successional forces, forest management practices, and natural disturbances significantly affects the region's composition of forest types. On a regional scale, data are insufficient for estimating the percentage of forest acres by cover type that have changed over time to a particular nonforest use. Several patterns have been observed, however. Pine area greatly increased as a result of depressed conditions in agriculture in the 1950's and 1960's, both through natural seeding and tree planting programs. A recent study (USDA 1983) suggests that substantial amounts of marginal cropland again exist under current economic conditions.

Cropland reversions have also contributed to recent increases in the upland hardwood area. The probability of cropland reversion to lowland hardwoods is much lower, especially on fertile bottom lands.

Lack of effort to regenerate pine after harvest also has helped to expand the hardwood area. Using FIA survey data, Boyce and Knight (1979) showed that there is substantial hardwood encroachment onto pine sites in the South, particularly after harvest or other disturbance of pine stands on NIPF land.

Pine is the forest type most frequently disturbed, regardless of the ownership type. According to FIA statistics, pine stands are disturbed about twice as often as hardwood stands (table 2). Hardwood stands are typically unmanaged or managed on much longer rotations than pine stands. In each major forest type, forest industry

Table 2.--Percentage distribution of timberland management practices between the last two survey remeasurements in Florida (1970-80), Georgia (1972-82), North Carolina (1974-84), and South Carolina (1967-77), by ownership and forest type

\begin{tabular}{|c|c|c|c|c|c|c|c|c|c|}
\hline \multirow[b]{2}{*}{ Ownership } & \multicolumn{3}{|c|}{ Pine } & \multicolumn{3}{|c|}{ Oak-pine } & \multicolumn{3}{|c|}{ Hardwood } \\
\hline & None & $\begin{array}{c}\text { Final } \\
\text { harvest }\end{array}$ & Other ${ }^{a}$ & None & $\begin{array}{c}\text { Final } \\
\text { harvest }\end{array}$ & other ${ }^{a}$ & None & $\begin{array}{c}\text { Final } \\
\text { harvest }\end{array}$ & other ${ }^{a}$ \\
\hline Forest & & & & & & & & & \\
\hline industry & $33 \cdot 3$ & 30.3 & 36.4 & 49.1 & 28.6 & 22.3 & 58.9 & 17.9 & 23.2 \\
\hline Farm & $33 \cdot 3$ & 22.7 & 44.0 & 48.3 & 19.8 & 31.9 & 58.0 & 14.7 & $27 \cdot 3$ \\
\hline $\begin{array}{l}\text { Miscellaneous } \\
\text { private }\end{array}$ & 36.8 & 22.4 & 40.8 & 51.9 & 18.0 & 30.1 & 63.1 & 11.6 & 25.3 \\
\hline
\end{tabular}

a "Other" management practices include thinning and other intermediate treatments, as well as natural disturbances. 
appears to have shorter rotations (i.e., more frequent final harvests) than other types of ownership, but the difference is not statistically significant.

What is clear from available data is that the area of pine plantation is increasing rapidly on forest industry land (fig. 2) and rather slowly on NIPF land (fig. 3). From 1977 to 1981, 65 percent of all the tree planting in the South was on forest industry land.

\section{Projections of Area Changes}

Area changes by forest ownership and cover type were projected to year 2030 in the Forest Service study of the southern timber situation. This distant date was necessary because of the longterm effects of area changes on the supply of timber in the South and on other renewable resources and the natural environment. Existing timber stands will be the primary source of timber over the next 20 to 30 years. Over a longer period, the supply of timber can be influenced to an increasing extent by land management actions.

The area projections were prepared in two phases: (1) area changes by use or ownership, and (2) area changes by forest type and forest ownerships (Alig 1985). The projections indicate that the major ownership changes will occur. in the NIPF categories (fig. 4). By

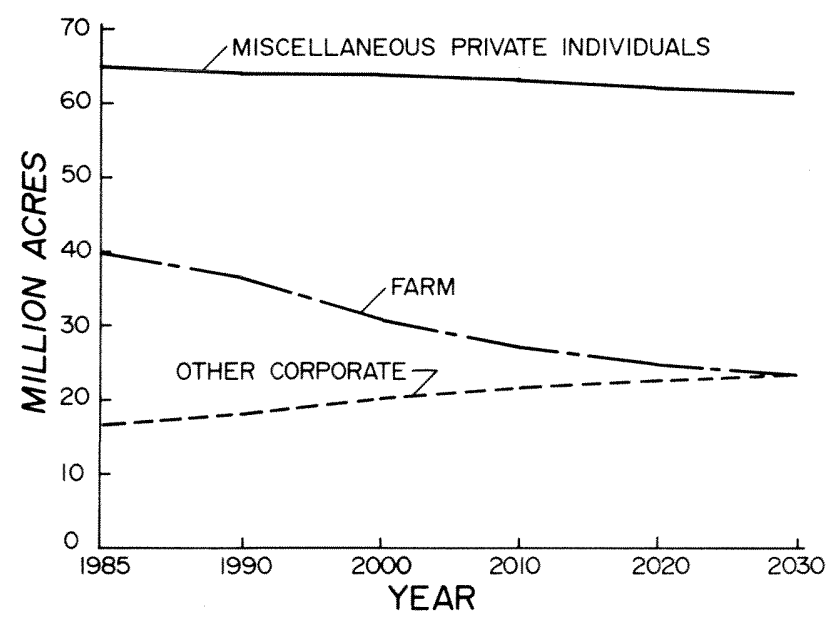

Pigure 4.--Projection of timberland area changes by ownership, 1985-2030.
2030, corporate and other individual owners together are projected to own half of the timberland. Conversely, the percentage of total timberland owned by farmers is projected to drop from 22 percent in 1985 to 14 percent in 2030 . Forest industry's share of the timberland base is projected to increase only slightly, in contrast to more rapid expansion in recent decades. Area in public ownership is projected to increase slowly, but to only 11 percent of total timberland in 2030 .

A 6-percent or 11-million-acre decrease in total timberland area is projected by 2030. Timberland area is expected to drop by 5 million acres in the Southeast and by 6 million acres in the Midsouth. General trends for projected area changes by State are similar to the regional trends.

A large part of the projected reduction in total timberland area is due to conversion to urban and built-up uses. Urban and related uses are projected to increase by 13 million acres between 1985 and 2030. Population in the South is projected by the U.S. Bureau of the Census to increase by over 30 million people by the year 2030 . Real income is likewise projected to increase substantially, more than doubling over the projection period.

A key step in making the projections was a decision about future changes in cropland area. Some forecasts are for increases in the area of cropland (USDA 1984). These projections depend largely on high agricultural exports, and exports have been declining in recent years. In addition, the 1985 Farm Bill instituted a Conservation Reserve designed to promote the conversion of highly erodible cropland to forest or grass cover.

Significance of the area in cropland related to the area in forest in the South is obvious. Figure 5 shows some of the possibilities. One is that 16 million acres currently in forest might be converted to cropland. Another is that 12 million acres now classed as marginal cropland could revert to forest. 
In this analysis, we assumed that the area in cropland would not rise above the current cropland area before 2030. We also projected a drop in southern pasture and rangeland of 8 million acres by 2030. We based this drop on an assumed continuation of the current decline in red meat consumption in the United States.

Projected area changes for the major forest types largely reflect recent historical trends (figs. 6, 7). The major area changes are projected to occur between the natural pine and planted pine types. Planted pine area doubles by 2030 , while natural pine area is projected to be halved by 2030 . Thus, the projected area in each in 2030 is roughly the reverse of the 1985 situation.

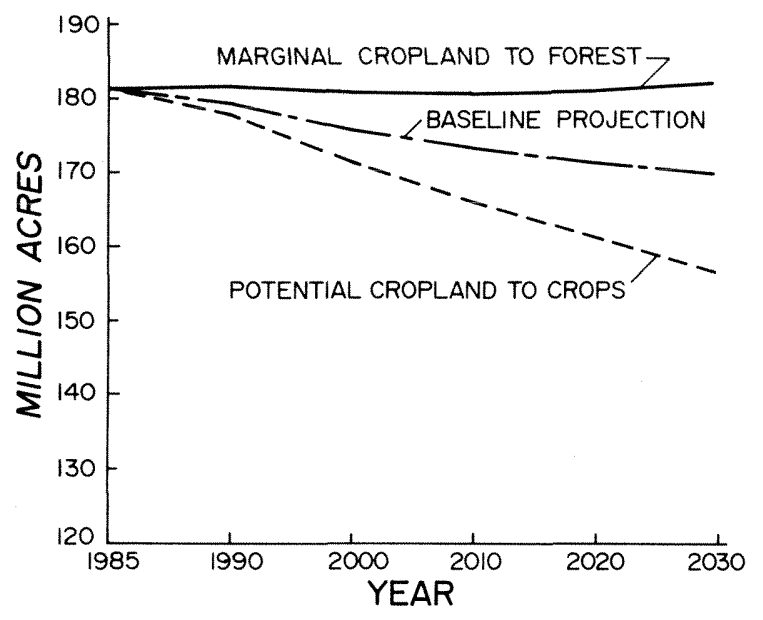

Pigure 5.--Alternative projections of total timberland area in the south.

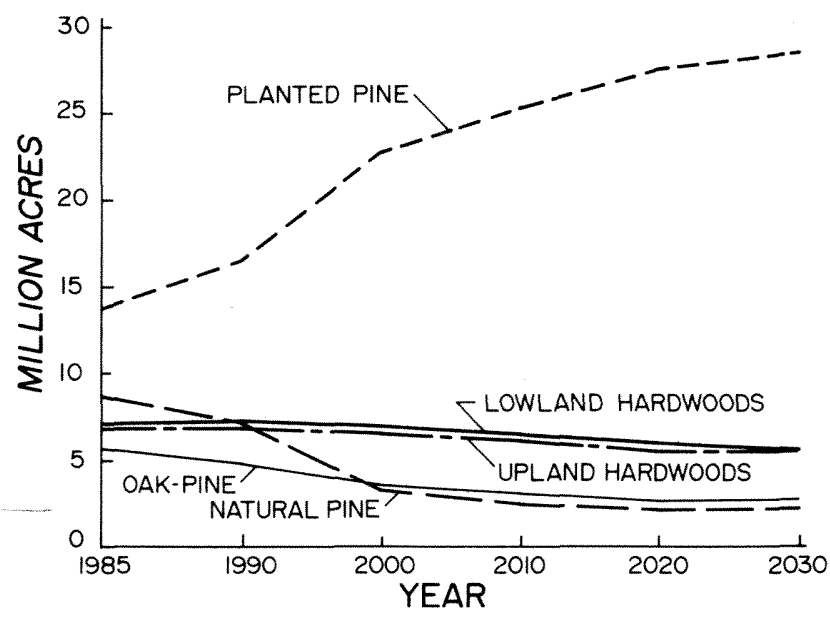

Figure 6.--Projection of forest industry timberland area by forest type, 1985-2030.
Two-thirds of the projected net increase in planted pine area between 1985 and 2030 is on timberland managed by forest industry. As a result, relatively little natural pine is projected to remain on forest industry land.

\section{Summary and Conclusions}

Southern timber is extremely important to the Nation's forest industry, and its importance will increase in the next decade or so as industry continues to migrate into the region from the Pacific Northwest. Since 1977, farm forest acreage has decreased, whereas the area owned by corporations other than forest products manufacturers has expanded. There has been a steady growth in the landholdings of forest industry and in pine planting by forest industry. Pine planting on other forest land has also increased somewhat. Forest acreage is being lost to urban and other developed uses, and a large reduction in natural pine acreage has been offset only partially by increased tree planting.

Projections indicate that corporate and other individual private owners will control half of the southern timberland base by 2030 and that forest industry will not continue to acquire land at past rates. Pine plantation area is projected to double by 2030, while the natural pine area is expected to be halved.

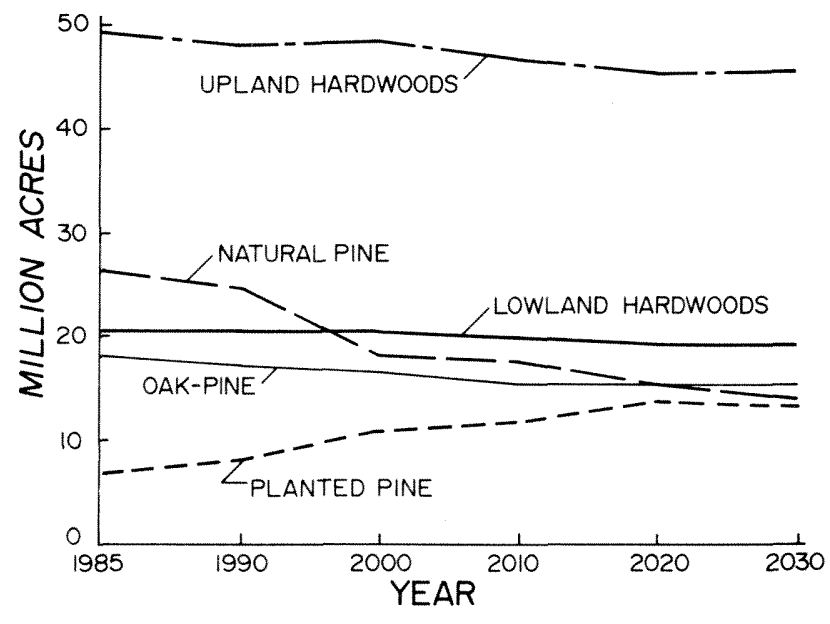

Figure 7---Projection of nonindustrial private timberland area by forest type, 1985-2030. 
Major land use questions emanate from outside the traditional forestry community: Will the acreage of cropland in the South increase or decrease? How heavily will other corporate owners invest in forest management? Will the increasing population in the South curtail opportunities for regional forestry expansion?

To better address such questions, changes in forest ownership and management and related land use changes will have to be monitored continuously, and analyses will have to be updated frequently. The USDA Forest Service is supporting such an effort--an ongoing study of the timber resources in the South. The work reported here is part of that effort.

\section{Literature Cited}

Alig. Ralph J. Porest acreage trends in the Southeast. econometric analysis and policy simulations. Corvallis, OR: Oregon state University; 1984. 154 pp. Thesis.

Alig, Ralph J, Modeling acreage changes in forest ownerships and cover types in the Southeast. Res. Pap. RM-260. Port Collins, Co: U.S. Department of Agriculture, Forest Service, Rocky Mountain Forest and Range Experiment Station; 1985. 14 pp.

Boyce, Stephen G.; Knight, Herbert A. Prospective ingrowth of southern pine beyond 1980. Res. Pap. SE-200. Asheville, NC: U.S. Department of Agriculture, Forest Service, Southeastern Porest Experiment station; 1979. 48 pp.
Clephane, Thomas $P$. Ownership of timber: a
critical component of industrial success.
Forest Industry $105(9): 30-32 ; 1978$.

Clephane, Thomas $P$. Timberland investment increasing as means of improving profitability. pulp and paper 54(11):72-73; 1980 .

Clephane, Thomas P.; Carro11, J. Timber: even nonindustry investors realize its value. Forest Industry $108(1): 49-51 ; 1981$.

Cousins, C.F.; Dillman, B.L. Prime agricultural land conversion in the Greenvil1e-SpartanburgPickens area. Clemson, sc: South Carolina Agriculture Experiment station; 1982. 46 pp.

Dideriksen, Raymond I.; Hidlebaugh, Allen R.; Schumde, Keith o. Potential cropland study. Stn. Bul1. 578; Washington, DC: U.S. Department of Agriculture, Sol1 Conservation Service; 1977. 104 pp.

Healy, Robert G. Forests in an urban civilization: land use, land markets, ownerships, and recent trends. In: Brad1ey, G.A., ed. Land use and forest resources in a changing environment: Proceedings of the national symposium on the urban forest interface; 1982 October 27-29; Seattle, WA: University of Washington Press; $1984: 17-35$.

Knight, Herbert A. Land-use changes which affected Georgia's forest land 1961-1972. Res. Note SE-189. Asheville, NC: U.S. Department of Agriculture, Porest service, Southeastern Forest Experiment station; 1973. 4 pp.

Meyer, R.D.; K1emperer, w. David. Current status of long-term leasing and cutting contracts in the South. In: Guldin, Richard w., ed. Payofes from new techniques for managing processing southern hardwoods: Proceedings, 1984 southern forest economics workshop; 1984 March 13-15; Memphis, TN. Raleigh, NC: Southern Porest Economics Workers; $1984: 125-130$.

o'Laughlin, Jay; Ellefson, Paul V. New diversified entrants among U.S. wood-based companies: a study of economic structure and corporate strategy. Bu11. 541. st. Paul, MN: University of Minnesota, Agriculture Experiment station; 1982. 63 pp. 
Ramsey, A.P.; Corty, F.L. Prime agricultural lands of Louisiana: location and losses to nonagricultural uses. Res. Pap. 596. Baton Rouge, LA: Louisiana state University, Department of Agricultural Economics and Agribusiness; 1982 . 28 PP.

Siege1, William C. Long-tern contracts for forest land and timber in the South. Res. Pap. So-87; New Orleans, LA: U.S. Department of Agriculture, Forest Service, Southern Porest Experiment station; $1973.14 \mathrm{pp}$.

U.S. Department of Agriculture. Reference document: needs assessment for the food and agricultural sciences. Washington, DC: Joint Council; 1984.316 pp.
U.S. Department of Agriculture, office of Budget and Program Analysis. Conversion of southern cropland to southern pine tree plantings: conversion for conservation feasibility study. washington, DC; 1983.63 pp.

U.S. Department of Agriculture, Porest Service. An analysis of the timber situation in the United states, 1952-2030. For. Resour. Rep. 23. Washington, DC; 1982. 499 pp. 
Alig, Ralph J.; Knight, Herbert A.; Birdsey, Richard A.

Recent area changes in southern forest ownerships and cover types. Res. Pap. SE-260. Asheville, NC: U.S. Department of Agriculture, Forest Service, Southeastern Forest Experiment Station; 1986. 10 pp.

Forest area data were examined from the most recent surveys of the 12 Southern States by the Forest Inventory and Analysis units of the USDA Forest Service. From 1977 to 1985, forest industry acreage in the South has continued to increase, miscellaneous private acreage has increased at a slower rate, and farm forest acreage has continued to drop sharply. During the same period, the largest area changes among cover types have occurred in pine types. Area in natural pine has decreased 18 percent, and planted pine area has increased by 41 percent.

KEYWORDS: Forest area, timber supply, forest ownership.
Alig, Ralph J.; Knight, Herbert A.; Birdsey, Richard A.

Recent area changes in southern forest ownerships and cover types. Res. Pap. SE-260. Asheville, NC: U.S. Department of Agriculture, Forest Service, Southeastern Forest Experiment Station; 1986. 10 pp.

Forest area data were examined from the most recent surveys of the 12 Southern States by the Forest Inventory and Analysis units of the USDA Forest Service. From 1977 to 1985, forest industry acreage in the South has continued to increase, miscellaneous private acreage has increased at a slower rate, and farm forest acreage has continued to drop sharply. During the same period, the largest area changes among cover types have occurred in pine types. Area in natural pine has decreased 18 percent, and planted pine area has increased by 41 percent. KEYWORDS: Forest area, timber supply, forest ownership. 